\title{
Biological strategy to improve decomposition of organic matter in tilapia pond
}

Estratégia biológica para incremento da decomposição de matéria orgânica em viveiros de tilápia

Gustavo Ruschel Lopes ${ }^{1 *}$ (D), Hugo Mendes de Oliveira $^{1}$ (D), Gabriel Fernandes Alves de Jesus ${ }^{1}$ (D),

Maurício Laterça Martins ${ }^{1}$ (D), Carlos Henrique Araújo de Miranda Gomes² (D), Thiago Soligo ${ }^{3}$ (D) and José Luiz Pedreira Mourińo

${ }^{1}$ Núcleo de Estudos em Patologia Aquícola, Centro de Ciências Agrárias, Universidade Federal de Santa Catarina - UFSC, Servidáo Caminho do Porto, s/n, Itacorubi, CEP 88034-257, Florianópolis, SC, Brasil

${ }^{2}$ Laboratório de Moluscos Marinhos, Centro de Ciências Agrárias, Universidade Federal de Santa Catarina - UFSC, Servidão Beco dos Coroas, 492, Barra da Lagoa, CEP 88061-615, Florianópolis, SC, Brasil

${ }^{3}$ DSM Animal Nutrition \& Health Latam, Heredia, Heredia, Costa Rica

*e-mail: gustavoruschel@gmail.com

Cite as: Lopes, G.R. et al. Biological strategy to improve decomposition of organic matter in tilapia pond. Acta Limnologica Brasiliensia, 2020, vol. 32, e27.

Abstract: Aim: The increment of decomposition of organic matter in sediment samples from Nile tilapia farms was evaluated with the introduction of Bacillus subtilis and B. licheniformis bacteria. Methods: Sediment samples placed in $18 \mathrm{~L}$ plastic boxes received single dose inoculum with the following concentrations: $1.21 \times 10^{6} \mathrm{CFU} \mathrm{g}^{-1}$ (equivalent to $75 \mathrm{~g} \mathrm{ha}^{-1}$ ), $2.41 \times 10^{6} \mathrm{CFU} \mathrm{g}^{-1}$ (equivalent to $150 \mathrm{~g} \mathrm{ha}^{-1}$ ), $4.82 \times 10^{6} \mathrm{CFU} \mathrm{g}^{-1}$ (equivalent to $300 \mathrm{~g} \mathrm{ha}^{-1}$ ) and $1.61 \times 10^{7} \mathrm{CFU} \mathrm{g}^{-1}$ (equivalent to $1000 \mathrm{~g} \mathrm{ha}^{-1}$ ), in addition to a control treatment with saline solution only. Organic matter content, total organic carbon (TOC) and oxidizable (OOC), total nitrogen (TN), ratios (TOC: $\mathrm{N}$ and OOC: N), clay content, $\mathrm{pH}$ in water, Shoemaker, McLean, Pratt index (SMP Index), phosphorus $(\mathrm{P})$, potassium $(\mathrm{K})$, calcium $(\mathrm{Ca})$ and magnesium $(\mathrm{Mg})$ contents, potential acidity $(\mathrm{H}+\mathrm{Al})$, cation exchange capacity $(\mathrm{CEC})$ at $\mathrm{pH} 7.0$, base saturation $(\mathrm{V})$ and sum of bases $(\mathrm{S})$. Results: The values of OM showed significant difference, between the lowest values (treatments 75, 150 and $300 \mathrm{~g} \mathrm{ha}^{-1}$ ) and the highest value, (control treatment). TOC, OOC, NT and their relationships (TOC: N and OOC: $\mathrm{N}$ ) showed significant differences between the mean values of the control treatment and the other treatments. Conclusions: The addition of Bacillus subtilis and B. licheniformis bacteria increased the decomposition rate of organic matter in sediments samples from Nile tilapia farms.

Keywords: aquaculture; bioremediation; Bacillus subtilis; Bacillus licheniformis; sediment.

Resumo: Objetivo: Foi avaliado o incremento da decomposição da matéria orgânica em amostras de sedimento de viveiros de criação de tilápias-do-Nilo com a introdução das bactérias Bacillus subtilis e B. licheniformis. Métodos: Amostras de sedimento colocadas em caixas plásticas de 18L, receberam dose única de inóculos com as seguintes concentrações: $1,21 \times 10^{6} \mathrm{UFC} \mathrm{g}^{-1}$ (equivalente a $\left.75 \mathrm{~g} \mathrm{ha}^{-1}\right), 2,41 \times 10^{6} \mathrm{UFC} \mathrm{g}^{-1}$ (equivalente a $150 \mathrm{~g} \mathrm{ha}^{-1}$ ), 4,82 x $10^{6} \mathrm{UFC} \mathrm{g}^{-1}$ (equivalente a $300 \mathrm{~g} \mathrm{ha}^{-1}$ ) e 1,61 $10^{7} \mathrm{UFC}^{-1}$ (equivalente a $1000 \mathrm{~g} \mathrm{ha}^{-1}$ ), além de um tratamento controle, com adiçáo apenas de solução salina. Foram analisados teor de matéria orgânica, teores de carbono orgânico total (COT) e oxidável (COO), nitrogênio total (NT), relaçôes de carbono: nitrogênio (COT:N e COO:N), teor de argila, $\mathrm{pH}$ em água, índce Shoemaker, McLean, Pratt (índice SMP), teores de fósforo (P), de potássio 
(K), de cálcio $(\mathrm{Ca})$ e de magnésio $(\mathrm{Mg})$, acidez potencial $(\mathrm{H}+\mathrm{Al})$, capacidade de troca catiônica $(\mathrm{CTC})$ a pH 7,0 e saturação por bases (V). Resultados: Os valores de $\mathrm{MO}$ apresentaram diferença significativa entre os menores valores (tratamentos 75, $150 \mathrm{e} 300 \mathrm{~g} \mathrm{ha}^{-1}$ ) e o maior valor (tratamento controle). COT, COO, NT e suas relaçôes (COT:N e COO:N) apresentaram diferenças significativas entre os valores médios do tratamento controle e os demais tratamentos. Conclusóes: A adição das bactérias Bacillus subtilis e $B$. licheniformis incrementou a taxa de decomposição de matéria orgânica em amostras de sedimento de viveiro de criação de tilápias-do-Nilo.

Palavras-chave: aquicultura; biorremediação; Bacillus subtilis; Bacillus licheniformis; sedimento.

Fish production is currently one of the main sources of animal protein for human consumption, having reached a record total of 171 million tons in 2016 (FAO, 2018). Among the fish species produced worldwide, Nile tilapia (Oreochromis niloticus Linnaeus, 1758) is the fourth with the highest production volume and the main in Brazil, reaching 400,280 tons in 2018, with significant annual growth rates (Medeiros, 2019). However, this intensification of crops also increases the generation of organic waste. In excavated tanks, organic matter ends up at the bottom at a rate of approximately 1-2 $\mathrm{cm}^{\text {year-1 }}{ }^{-1}$ (Boyd et al., 2010). As the main fish breeding in Brazil, tilapia culture presents itself as an activity with great potential for eutrophication of farming environments, as well as surrounding areas (Coldebella et al., 2017).

A possible biological strategy for better management of accumulated organic matter in fish ponds is bioremediation, which is the transformation of contaminants, mediated by organisms and/or their enzymes, into non-toxic or less harmful substances (Karigar \& Rao, 2011). Some bacteria have a recognized action on the decomposition of organic matter (De Marco et al., 2017), such as those of the genus Bacillus sp., which are producers of important hydrolytic enzymes in this process such as proteases (Degering et al., 2010), lipases. (Iqbal \& Rehman, 2015), amylases (Raul et al., 2014), chitinases (Trachuk et al., 1996), cellulases (De Marco et al., 2017) and xylanases (Yoon, 2009; Yi et al., 2011).

The aim of this study was to evaluate on a laboratory scale the ability of $B$. subtilis and $B$. licheniformis to decompose organic matter from sediments of intensive fish farms. For this purpose, sediment samples were collected the day after the end of the production cycle of a fish farm $\left(5,500 \mathrm{~m}^{2}\right)$ located in Armazém, SC, Brazil (S 28 10,942'W0 $\left.49^{\circ} 00,861^{\prime}\right)$.

The product tested in the present study was PureGro ${ }^{\circ}$, manufactured by the Netherlands-based company DSM Nutritional Products Inc., containing mineral oil, rice husk, calcium carbonate and probiotic bacteria Bacillus subtilis and B. licheniformis at the estimated concentration of $1.12 \times 10^{9} \mathrm{CFU} \mathrm{g}^{-1}$. The inoculum was diluted in saline solution $(0.65 \%$ $\mathrm{NaCl}$ ) at different concentrations, adjusting the fixed final volume of $30 \mathrm{~mL}$ per experimental unit for subsequent application on the sediment.

The experiment was carried out in experimental units consisting of $18 \mathrm{~L}$ plastic boxes, measuring $41 \times 34 \times 13 \mathrm{~cm}$ (length $\mathrm{x}$ width $\mathrm{x}$ height), filled with sediment to the approximate height of $10 \mathrm{~cm}$. The design used consisted of four treatments with the addition of bacteria inoculum at the following concentrations: $1.21 \times 10^{6} \mathrm{CFUg}^{-1}$ (equivalentto $75 \mathrm{gha}^{-1}$ ), $2.41 \times 10^{6} \mathrm{CFU} \mathrm{g}^{-1}$ (equivalent to $150 \mathrm{~g} \mathrm{ha}^{-1}$ ), $4.82 \times 10^{6} \mathrm{CFU} \mathrm{g}^{-1}$ (equivalent to $300 \mathrm{~g} \mathrm{ha}^{-1}$ ) and $1.61 \times 10^{7} \mathrm{CFU} \mathrm{g}^{-1}$ (equivalent to $1000 \mathrm{~g} \mathrm{ha}^{-1}$ ), plus a control treatment, with the addition of saline solution only. The experiment lasted nine days, with a single inoculum application on the first day, and with average sediment temperature in the experimental units of $24.08^{\circ} \mathrm{C} \pm 1.92$.

To perform the physicochemical analyzes of the different treatments, samples of $800 \mathrm{~mL}$ of sediment were collected nine days after inoculum application and dried in an oven at $60{ }^{\circ} \mathrm{C}$ for 48 hours. The determination of the organic matter (OM) contents was made by the colorimetric method by potassium dichromate reduction (Silva, 2009). Total organic carbon (TOC) and oxidizable organic carbon (OOC) of the sediment were estimated based on the organic matter content through the expressions: $\mathrm{TOC}=0.51(\mathrm{MO}-1)+0.48$ and $\mathrm{OOC}=0.51(\mathrm{MO}$ - 1) - 3.59, developed by Navarro et al. (1993). Based on the TOC, OOC and TN values (described below), carbon: nitrogen ratios (TOC: $\mathrm{N}$ and OOC: $\mathrm{N}$ ) were determined. Total nitrogen (TN) was analyzed by the Kjeldahl method (APHA, 2005). The analysis of the clay contents was performed by shear with marbles and reading in densimeter, according to (Tedesco et al., 1995). The $\mathrm{pH}$ analysis in water was performed by the electrochemical method through the effective concentration of $\mathrm{H}^{+}$ions in the sediment solution (Teixeira et al., 2017). Based on $\mathrm{pH}$ measurements in water, the SMP index was determined (Silva, 2009). Phosphorus, potassium, 
calcium and magnesium contents were determined according to the methodology of Teixeira et al. (2017) and the potential acidity of the sediment $(\mathrm{H}+\mathrm{Al})$ was determined according to the methodology described by Campos et al. (2017). The sum of bases $(S)$, cation exchange capacity $(\mathrm{T})$ and saturation of potential acidity $(\mathrm{V})$ were determined according to Teixeira et al. (2017).

Prior to data analysis, the Kolmogorov-Smirnov test was used to check for data normality and the Levene test for homogeneity of variance. In the present study, all the original datasets conformed to a normal distribution, and the potential differences among treatments were analyzed using one-way followed by Student-Newman-Keuls (SNK) test. One-way ANOVA was used to determine the differences among soil properties at $\mathrm{P}<0.05$. All data in the figures and tables are presented with original data, and they are presented as mean \pm SD (standard deviation).

The observed OM levels, ranging from $37.00 \mathrm{~g} \mathrm{~kg}^{-1}$ to $45.33 \mathrm{~g} \mathrm{~kg}^{-1}$ are within the range considered appropriate for fish farming
(Boyd et al., 2002). Significant differences were observed between the mean values of the control treatment and the other treatments (Table 1). Treatments 75, 150 e $300 \mathrm{~g} \mathrm{ha}^{-1}$ had the lowest content, indicating that the introduction of Bacillus subtilis and $B$. licheniformis increased the rate of decomposition of organic matter in the sediment samples.

Organic carbon is the major component of soil organic matter and energy source for heterotrophic microorganisms (Boyd et al., 2002; Madigan et al., 2010). In the present study, total organic carbon (TOC), oxidizable organic carbon (OOC) and their relationship to total nitrogen (TOC: $\mathrm{N}$ and OOC: $N$ ) showed significant differences between the mean values of the control treatment and the other treatments (Table 1). Treatments 75 , 150 e $300 \mathrm{~g} \mathrm{ha}^{-1}$ presented the lowest values in all the mentioned parameters, with reductions ranging from approximately 18 to $22 \%$. The total nitrogen contents of the treatments 75,150 and $300 \mathrm{~g} \mathrm{ha}^{-1}$ were different from the control (Table 1).

Table 1. Chemical and physical variables of fish sediments treated with different concentrations of $B$. subtilis and B. licheniformis in vitro estimation model.

\begin{tabular}{|c|c|c|c|c|c|c|c|c|c|c|c|}
\hline \multirow{2}{*}{ Treatment } & \multicolumn{2}{|c|}{$0 \mathrm{~g} \mathrm{ha}^{-1}$} & \multicolumn{2}{|c|}{$75 \mathrm{~g} \mathrm{ha}^{-1}$} & \multicolumn{2}{|c|}{$150 \mathrm{~g} \mathrm{ha}^{-1}$} & \multicolumn{2}{|c|}{$300 \mathrm{~g} \mathrm{ha}^{-1}$} & \multicolumn{2}{|c|}{$1000 \mathrm{~g} \mathrm{ha}^{-1}$} & \multirow{2}{*}{$P$ value } \\
\hline & Mean & S.D. & Mean & S.D. & Mean & S.D. & Mean & S.D. & Mean & S.D. & \\
\hline OM g kg-1 & $45.33^{a}$ & 1.53 & $41.00^{\mathrm{bc}}$ & 1.73 & $37.00^{c}$ & 2.00 & $40.00^{b c}$ & 1.73 & $42.00^{b}$ & 2.00 & .003 \\
\hline TOC g kg $^{-1}$ & $23.09^{a}$ & 0.78 & $20.88^{\mathrm{bc}}$ & 0.88 & $18.84^{c}$ & 1.02 & $20.37^{b c}$ & 0.88 & $21.39^{b}$ & 1.02 & 0.003 \\
\hline OOC g kg ${ }^{-1}$ & $19.02^{\mathrm{a}}$ & 0.78 & $16.81^{\mathrm{bc}}$ & 0.88 & $14.77^{c}$ & 1.02 & $16.30^{b c}$ & 0.88 & $17.32^{\mathrm{b}}$ & 1.02 & 0.003 \\
\hline $\mathrm{TN}_{\mathrm{g} \mathrm{kg}} \mathbf{~ g}^{-1}$ & $1.16^{\mathrm{a}}$ & 0.05 & $1.32^{\mathrm{b}}$ & 0.00 & $1.29^{b}$ & 0.05 & $1.29^{b}$ & 0.05 & $1.23^{\mathrm{ab}}$ & 0.00 & 0.007 \\
\hline TOC:N & $19.88^{a}$ & 1.47 & $15.81^{\mathrm{bc}}$ & 0.67 & $14.63^{c}$ & 1.00 & $15.84^{\mathrm{bc}}$ & 1.39 & $17.44^{b}$ & 0.83 & 0.002 \\
\hline OOC:N & $16.39^{a}$ & 1.32 & $12.73^{\mathrm{bc}}$ & 0.67 & $11.47^{c}$ & 0.92 & $12.68^{\mathrm{bc}}$ & 1.25 & $14.12^{\mathrm{b}}$ & 0.83 & 0.002 \\
\hline Clay g kg-1 & 30.67 & 0.58 & 29.67 & 2.08 & 28.67 & 2.08 & 28.67 & 1.53 & 28.67 & 1.53 & 0.511 \\
\hline pH-Water 1:1 & 6.77 & 0.06 & 6.80 & 0.00 & 6.73 & 0.06 & 6.77 & 0.06 & 6.77 & 0.06 & 0.655 \\
\hline SMP Index & 6.57 & 0.12 & 6.53 & 0.06 & 6.50 & 0.00 & 6.60 & 0.10 & 6.57 & 0.06 & 0.596 \\
\hline$P$ mg dm ${ }^{-3}$ & 390.20 & 13.36 & 381.10 & 2.13 & 379.40 & 3.30 & 368.10 & 7.07 & 377.50 & 9.27 & 0.082 \\
\hline $\mathrm{K} \mathrm{mg} \mathrm{dm}^{-3}$ & $324.80^{\mathrm{ab}}$ & 15.80 & $312.67^{b}$ & 7.57 & $318.27^{\mathrm{b}}$ & 3.52 & $345.93^{a}$ & 12.07 & $323.67^{a b}$ & 6.91 & 0.022 \\
\hline Ca cmolc dm ${ }^{-3}$ & 7.27 & 0.21 & 7.50 & 0.40 & 6.63 & 0.50 & 6.93 & 0.12 & 6.67 & 0.47 & 0.067 \\
\hline Mg cmolc $\mathrm{dm}^{-3}$ & 3.23 & 0.45 & 3.07 & 0.06 & 3.03 & 0.12 & 2.97 & 0.21 & 2.77 & 0.21 & 0.302 \\
\hline $\begin{array}{l}\text { Potential acidity } \\
\mathrm{H}+\mathrm{Al} \mathrm{cmolc} \mathrm{dm}^{-3}\end{array}$ & 2.33 & 0.29 & 2.33 & 0.06 & 2.40 & 0.00 & 2.20 & 0.10 & 2.33 & 0.15 & 0.630 \\
\hline $\begin{array}{l}\text { CEC pH7.0 cmolc } \\
\mathrm{dm}^{-3}\end{array}$ & 13.64 & 0.41 & 13.71 & 0.39 & 12.87 & 0.61 & 13.01 & 0.39 & 12.63 & 0.61 & 0.083 \\
\hline Base saturation - V & 82.89 & 2.10 & 82.99 & 0.63 & 81.30 & 0.89 & 83.10 & 0.36 & 81.47 & 1.83 & 0.337 \\
\hline Sum of bases - $S$ & 11.31 & 0.45 & 11.38 & 0.39 & 10.47 & 0.61 & 10.81 & 0.30 & 10.30 & 0.71 & 0.096 \\
\hline
\end{tabular}

Lower case letters indicate statistical difference between treatments $(\mathrm{P}<0.05) . \mathrm{OM} \mathrm{g} \mathrm{kg}^{-1}=$ Organic Matter content; TOC $\mathrm{g} \mathrm{kg}^{-1}=$ Total Organic Carbon content; OOC $\mathrm{g} \mathrm{kg}^{-1}=$ Oxidizable Organic Carbon content; $\mathrm{TN}_{\mathrm{kg}} \mathrm{k}^{-1}$ Total Nitrogen content; TOC: $\mathrm{N}$ = Total Organic Carbon: Nitrogen ratio; OOC:N = Oxidizable Organic Carbon: Nitrogen ratio; Clay g kg ${ }^{-1}=$ Clay content; $\mathrm{pH}-$ Water 1:1 $=$ Soil $\mathrm{pH}$ in a 1:1 soil: water suspension; SMP Index = Shoemaker, McLean, Pratt index; $\mathrm{P} \mathrm{mg} \mathrm{dm}{ }^{-3}=$ Phosphorus content; $\mathrm{K} \mathrm{mg} \mathrm{dm}{ }^{-3}=$ Potassium content; $\mathrm{Ca} \mathrm{cmolc} \mathrm{dm}^{-3}=$ Calcium content; $\mathrm{Mg} \mathrm{cmolc} \mathrm{dm}^{-3}=$ Magnesium content; Potential acidity $\mathrm{H}+\mathrm{Al} \mathrm{cmolc} \mathrm{dm}^{-3}=$ Potential acidity; CEC $\mathrm{pH} 7.0 \mathrm{cmolc} \mathrm{dm}^{-3}=$ Cation Exchange Capacity at $\mathrm{pH} 7.0$; Base saturation $-\mathrm{V}=$ Base saturation; Sum of bases $-S=$ Sum of bases; S.D = Standard Deviation . 


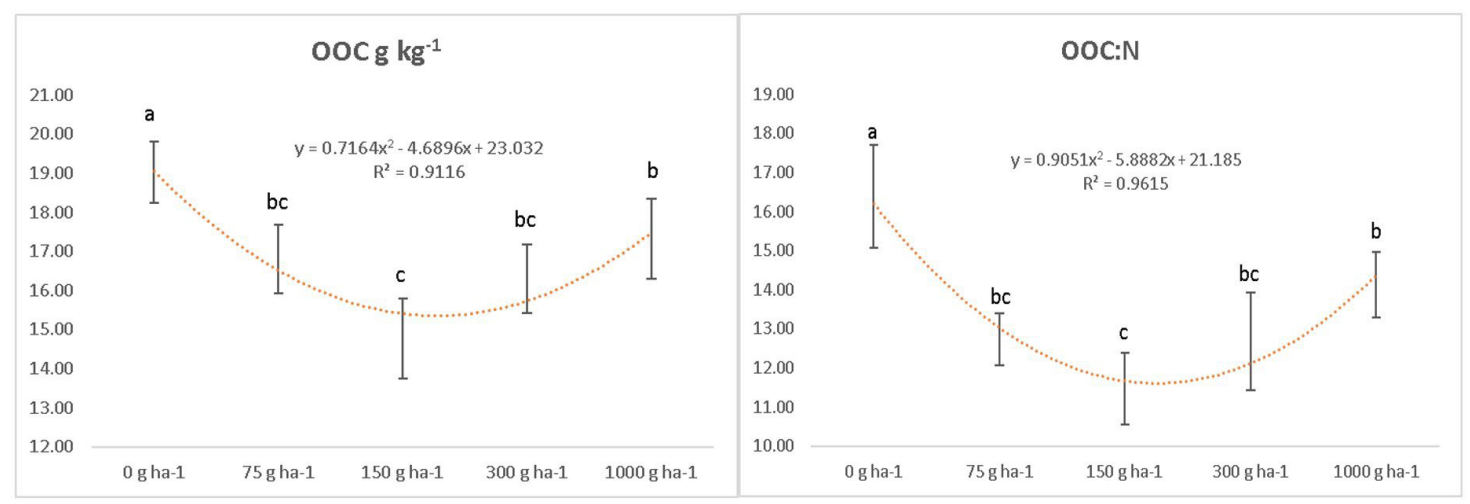

Figure 1. Estimation of a regression model of OOC (Oxidable carbon) and OOC:N (ratio of Total nitrogen and oxidable carbon) per different doses of $B$. subtilis and B. licheniformis in pond soil samples in an in vitro model.

The values of clay content, $\mathrm{pH}$ in water, SMP index, phosphorus $(\mathrm{P})$, potassium $(\mathrm{K})$, calcium $(\mathrm{Ca})$ and magnesium $(\mathrm{Mg})$ contents, potential acidity $(\mathrm{H}+\mathrm{Al})$, exchange capacity cationic acid (CTC) at $\mathrm{pH} 7.0$ and base saturation $(\mathrm{V} \%)$ are within their normal range for fish pond sediments and can be seen in Table 1.

At Figure 1, can be observed that when the doses increased, at a mean level, no more degradation of the organic matter can be observed in this model. So, it can be concluded that the minimal dosage of use $B$. subtilis and $B$. licheniformis is $1,21 \times 10^{6} \mathrm{UFC} \mathrm{g}^{-1}$ soil pond.

Due to advantages of these model of evaluation, the use of Bacillus subtilis e B. licheniformis has been applied efficiently to detect the varying correlations between soil attributes and the different doses applied. We concluded that the addition of Bacillus subtilis and B. licheniformis at a minimum dosage of $75 \mathrm{~g}$ ha- 1 is a way to increase the decomposition rate of organic matter in sediments samples from Nile tilapia farms, which can enhance the sustainability and an environmentally friendly biological approach to improve decomposition of organic matter in tilapia pond.

\section{Acknowledgements}

The authors thank the Conselho Nacional de Desenvolvimento Científico e Tecnológico $(\mathrm{CNPq})$ for the financial support and research grants to J.L.P. (CNPq 308292/2014-6) and M.L. Martins (CNPq 305869/2014-0) J.L.P., the Coordenação de Aperfeiçoamento de Pessoal de Nível Superior (CAPES) by the doctoral scholarship of the student G.R. Lopes. The authors would also like to thank the DSM Nutritional Products Inc. for the support.

\section{References}

AMERICAN PUBLIC HEALTH ASSOCIATION APHA. Standard methods for the examination of water and wastewater. 21st ed. Washington: APHA, 2005.

BOYD, C.E., WOOD, C.W. and THUNJAI, T. Aquaculture pond bottom soil quality management. Corvalis: PD/ACRSP, 2002.

BOYD, C.E., WOOD, C.W., CHANEY, P.L. and QUEIROZ, J.F. Role of aquaculture pond sediments in sequestration of annual global carbon emissions. Environmental Pollution, 2010, 158(8), 2537-2540. http://dx.doi.org/10.1016/j.envpol.2010.04.025. PMid:20537775.

CAMPOS, D.V.B., TEIXEIRA, P.C., PÉREZ, D.V. and SALDANHA, M.F.C. Acidez potencial do solo. In: P.C. TEIXEIRA, G.K. DONAGEMMA, A. FONTANA and W.G. TEIXEIRA, eds. Manual de métodos de análise de solo. Brasília: Embrapa, 2017, pp. 233-237.

COldebella, A., GENTElini, A., PIANA, P., COLDEBELLA, P., BOSCOLO, W. and FEIDEN, A. Effluents from fish farming ponds: a view from the perspective of its main components. Sustainability, 2017, 10(1), 1-16. http://dx.doi.org/10.3390/ su10010003.

DE MARCO, E.G., HECK, K., MARTOS, E.T. and VAN DER SAND, S.T. Purification and characterization of a thermostable alkaline cellulase produced by Bacillus licheniformis 380 isolated from compost. Annals of the Brazilian Academy of Sciences, 2017, 89(3, Suppl.), 2359-2370. http:// dx.doi.org/10.1590/0001-3765201720170408. PMid:29044330.

Degering, C., EgGert, T., PUls, M., BONGAERTS, J., EVERS, S., MAURER, K. and JAEGER, K. Optimization of protease secretion in Bacillus subtilis and Bacillus licheniformis by screening of homologous and heterologous signal peptides. Applied and Environmental Microbiology, 2010, 76(19), 
6370-6376. http://dx.doi.org/10.1128/AEM.0114610. PMid:20709850.

FOOD AND AGRICULTURE ORGANIZATION

- FAO. The state of world fisheries and aquaculture 2018: meeting the sustainable development goals. Rome: FAO, 2018.

IQBAL, S.A. and REHMAN, A. Characterization of lipase from Bacillus subtilis I-4 and its potential use in oil contaminated wastewater. Brazilian Archives of Biology and Technology, 2015, 58(5), 789-797. http://dx.doi. org/10.1590/S1516-89132015050318.

KARIGAR, C.S. and RAO, S.S. Role of microbial enzymes in the bioremediation of pollutants: a review. Enzyme Research, 2011, 2011, 805187. http://dx.doi. org/10.4061/2011/805187. PMid:21912739.

MADIGAN, M.T., MARTINKO, J.M., STAHL, D.A. and CLARK, D.P. Brock biology of microorganisms. 13th ed. San Francisco: Benjamin Cummings, 2010.

MEdeIROS, F. Anuário Peixe BR da Piscicultura 2019. São Paulo: Associação Brasileira da Piscicultura, 2019.

NAVARRO, A.F., CEGARRA, J., ROIG, A. and GARCIA, D. Relationships between organic matter and carbon contents of organic wastes. Bioresource Technology, 1993, 44(3), 203-207. http://dx.doi. org/10.1016/0960-8524(93)90153-3.

RAUL, D., BISWAS, T., MUKHOPADHYAY, S., KUMAR DAS, S. and GUPTA, S. Production and partial purification of alpha amylase from Bacillus subtilis (MTCC 121) using solid state fermentation. Biochemistry Research International, 2014, 2014, 568141. http://dx.doi.org/10.1155/2014/568141. PMid:24672727.
SILVA, F.C. Manual de análises químicas de solos, plantas e fertilizantes. 2. ed. Brasília: Embrapa Informação Tecnológica, 2009.

TEDESCO, M.J., GIANELLO, C., BISSANI, C.A., BOHNEN, H. and VOLKWEISS, S.J. Análise de solo, plantas e outros materiais. 2. ed. Porto Alegre: Departamento de Solos, Universidade Federal do Rio Grande do Sul, 1995.

TEIXEIRA, P.C., DONAGEMMA, G.K., FONTANA, A. and TEIXEIRA, W.G. Manual de métodos de análise de solo. Brasília: Embrapa, 2017.

TRACHUK, L.A., REVINA, L.P., SHEMYAKINA, T.M., CHESTUKHINA, G.G. and STEPANOV, V.M. Chitinases of Bacillus licheniformis B-6839: isolation and properties. Canadian Journal of Microbiology, 1996, 42(4), 307-315. http://dx.doi. org/10.1139/m96-046.

YI, P., PAI, C. and LIU, J. Isolation and characterization of a Bacillus licheniformis strain capable of degrading zearalenone. World Journal of Microbiology \& Biotechnology, 2011, 27(5), 1035-1043. http://dx.doi. org/10.1007/s11274-010-0548-7.

YOON, K.-H. Cloning of the Bacillus subtilis AMX4 Xylanase gene and characterization of the gene product. Journal of Microbiology and Biotechnology, 2009, 19(12), 1514-1519. http://dx.doi.org/10.4014/ jmb.0907.07004. PMid:20075612.

Received: 30 September 2019 Accepted: 21 August 2020

Associate Editor: Gustavo Henrique Gonzaga da Silva. 